\title{
MAXIMUM LOCOMOTOR SPEED OF THE BEST FOOTBALL PLAYERS AT THE FFFA WORLD CUP IN BRAZZL
}

\author{
Łukasz Bojkowski, ${ }^{1, A, B, C, D}$ Robert Śliwowski, ${ }^{2, \text { D, E}}$ Andrzej Wieczorek², D, E \\ 1 Division of Physical Activity and Health Promotion Science, University School of Physical Education, Poznań, Poland \\ 2 Division of Theory and Methodology of Team Sport Games, University School of Physical Education, Poznań, Poland \\ A Study Design; ${ }^{B}$ Data Collection; ${ }^{\mathrm{C}}$ Statistical Analysis, ${ }^{\mathrm{D}}$ Manuscript Preparation; ${ }^{\mathrm{E}}$ Funds Collection
}

\author{
Address for correspondence: \\ Łukasz Bojkowski \\ Division of Physical Activity and Health Promotion Science \\ University School of Physical Education \\ Królowej Jadwigi 27/39, 61-871 Poznań, Poland \\ E-mail: bojkowski@awf.poznan.pl
}

\begin{abstract}
Ahstract In comprehensive preparation of a player to football competition special attention is paid to his predispositions in terms of speed abilities. Therefore, the authors' objective was to analyse maximum locomotor speed of players of the four best national teams competing during the FIFA World Cup in Brazil, including specifying the differences in terms of speeds of these national teams and players in corresponding playing positions of individual teams.

The analysis used data obtained using the Castrol Performance Index, a kinematic method and in order to present significance of differences between the studied teams and playing positions one-way analysis of variance (ANOVA) was performed.

The study showed that the mean maximum running speed of the players of the four best teams of the World Cup was 8.34 metres/ second. The mean maximum locomotive speed of the defenders in semi-finalist teams of the tournament was $8.29 \mathrm{~m} / \mathrm{s}$, while the midfielders' speed was $-8.16 \mathrm{~m} / \mathrm{s}$, the forwards' $-8.48 \mathrm{~m} / \mathrm{s}$ and the goalkeepers' $-7.40 \mathrm{~m} / \mathrm{s}$. The players who had a maximum speed of $9 \mathrm{~m} / \mathrm{s}$ or more were the Dutchman Ron Vlaar $(9.16 \mathrm{~m} / \mathrm{s})$ and the Argentines José María Basanta $(9.09 \mathrm{~m} / \mathrm{s})$ and Ángel Di Maria $(9.17 \mathrm{~m} / \mathrm{s})$. There is no significant difference between the world's best teams, including between their corresponding playing positions, in the level of maximum running speeds determining the dynamics of the game.
\end{abstract}

Key worlls football, speed, World Cup

\section{Introduction}

Locomotor activity is related to athlete's moving around (Soroka, 2011). The profile of forms of locomotion during a football match includes such activities as walk, jog, slow run, backward run, moderate run, high speed run and sprint (Bangsbo, 1999; Mohr et al., 2003; Bradley et al., 2009). During a sprint the maximum speed of motion an athlete can reach is approximately $9 \mathrm{~m} / \mathrm{s}$. On average a player performs 46 sprints during a football game (30 to 40 according to Soroka, 2011), which last from 2 to 4 seconds (Bangsbo et al., 1991; Soroka, 2011). They are performed in situations when a player tries to run away from an actively attacking or defending opponent or to run into a free 
space to make a shot or perform a so called "key pass" (Faude et al., 2012). The studies have shown that during a match a player covers in total 200 to 350 metres (from 215 to 446 metres according to Di Salvo et al. (2007)), from 179 to 334 metres according to Lago et al. (2010) from 199 to 290 metres according to Dellal et al. (2011), from 167 to 345 metres according to Bompa et al. (2013) by sprinting.

The study of Bradley et al. (2009) carried out on 370 players of the English Premier League competing in the $2005 / 2006$ season showed that on average sprinting takes $0.6 \%$ of the whole play time of a highly effective player during a football game. On the basis of their analysis Mohr et al. (2003) established that this time accounts for $1.4 \%$ of total playing time. Nevertheless, the ability to perform short fast runs, so called sprints, and their quality may be very important for the final success in a situation of direct sport competition (Cometti et al., 2001). Chmura (2001) wrote that a player who "is a few centimetres closer to a ball, a few milliseconds faster at the ball then his opponent, may score the decisive goal, or stop the opposition from scoring one".

In this study the authors took up the problem of maximum speeds which are some of the elementary "indicators" showing the dynamics of play of a team (Chmura et al., 2010), reached by the players of the four best teams at the 2014 World Cup in Brazil. Like other championship tournaments, the World Cup provided an opportunity to watch changes taking place in the game using the example of professional players. The analysis of the teams characterised by the top level of sports advancement is to help in determining the speed requirements in terms of locomotor speed in a football game played by world class players.

\section{Methodology of study}

The aim of this study was the analysis of maximum locomotor speeds of players of the four best teams of the 2014 World Cup, i.e. national teams of Germany (the current world champions), Argentina (vice champions), Netherlands (bronze medallists) and Brazil. Moreover, the aim was to specify the differences in results of the teams and players in corresponding playing positions of individual teams. The following research questions were used to achieve the aim of the study:

1. What was the mean maximum speed of the first four teams of the 2014 World Cup during the tournament?

2. What were the mean maximum speeds of the individual playing positions of the four best teams of the World Cup finals in Brazil during the tournament?

3. Were there any players in the four best teams of the 2014 World Cup whose maximum locomotor speed was $9 \mathrm{~m} / \mathrm{s}$ or more?

4. Were there significant differences in the mean maximum locomotor speeds between the teams and the corresponding playing positions of these teams?

The study covered football players representing the best teams of the FIFA World Cup in Brazil, that is the finalists of the tournament and the teams which competed for the third position. Only players who played for at least 90 minutes during the whole tournament were taken into consideration. What is important, the analysis included also the data obtained during so called "extra times". During the World Cup, from 12th of June to 13th of July 2014, all analysed teams played seven games (three in the group stage, 1/8th of the final, quarter finals, semi-final and the game for the 3 rd place or the final). In total the results obtained by 68 players in 24 championship games were analysed. 
In the analysis statistical data prepared on the basis of the Castrol Performace Index (fifa.com/castrolindex, access on 20.07.2014), using a kinematic method, an objective system of game analysis, were used. The method uses semi-automatic cameras in order to monitor events in each sector of the pitch during a sport competition. The data obtained using this system are commonly used in many scientific studies.

Thanks to a database of available data, mean maximum speeds were calculated for:

1. Teams, where the total of maximum speeds of all players of a given team was divided by the number of players of the team included in the analysis.

2. Players in individual playing positions, where the total of maximum speeds of players in certain playing position of a given team was divided by the number of players of the team included in the analysis.

3. Individual players, where the maximum locomotor speed of a player in each game was established and the highest value of the indicator in the tournament was used for the analysis.

Then the results presented in reports in $\mathrm{km} / \mathrm{h}$ were translated into $\mathrm{m} / \mathrm{s}$ (both values were presented in the description of the results). For a mathematical analysis of results descriptive statistics was used and in order to demonstrate significance of differences between the studied teams and corresponding playing positions oneway analysis of variance (ANOVA) was performed. The descriptive statistics and calculations were performed in STATISTICS 10.0 PL, StatSoft Polska.

\section{Resullts}

The analysis of the four best teams of the tournament showed that the mean maximum running speed of the representatives of Germany $(n=14)$, Argentina $(n=17)$, the Netherlands $(n=15)$ and Brazil $(n=18)$ in the studied 24 games was 8.34 metres/second (30.04 kilometres/hour). The Argentine players had the mean speed of $8.42 \mathrm{~m} / \mathrm{s}$ $(30.32 \mathrm{~km} / \mathrm{h})$, the Brazilian players $-8.31 \mathrm{~m} / \mathrm{s}(29.90 \mathrm{~km} / \mathrm{h})$, the German players $-8.25 \mathrm{~m} / \mathrm{s}(29.70 \mathrm{~km} / \mathrm{h})$ and the Dutch players $-8.20 \mathrm{~m} / \mathrm{s}(29.51 \mathrm{~km} / \mathrm{h})$. In the calculation of the mean maximum speeds of individual teams, the speeds of goalkeepers were not taken into consideration. Standard deviation for all results was 1.61 .

Among the analysed players three players, i.e. two defenders and one offensive midfielder, had maximum speeds of $9 \mathrm{~m} / \mathrm{s}$ or more. The defenders included the Argentine José María Basanta $-9.09 \mathrm{~m} / \mathrm{s}(32.72 \mathrm{~km} / \mathrm{h})$ and the Dutchman Ron Vlaar whose maximum running speed in the tournament was $9.16 \mathrm{~m} / \mathrm{s}$ (32.98 km/h). The midfielder was the Argentine Ángel Di Maria who had the maximum speed of $9.17 \mathrm{~m} / \mathrm{s}(33.01 \mathrm{~km} / \mathrm{h})$.

The mean result of defenders of the best "four" of the tournament was $8.29 \mathrm{~m} / \mathrm{s}(29.86 \mathrm{~km} / \mathrm{h})$. The analysis of the top running speeds of individual defenders indicated that the Argentine players had the mean maximum speed of $8.58 \mathrm{~m} / \mathrm{s}(30.87 \mathrm{~km} / \mathrm{h})$, the Dutch players $-8.29 \mathrm{~m} / \mathrm{s}(29.85 \mathrm{~km} / \mathrm{h})$, the German players $-8.18 \mathrm{~m} / \mathrm{s}(29.50 \mathrm{~km} / \mathrm{h})$ and the representatives of Brazil $-8.16 \mathrm{~m} / \mathrm{s}(29.38 \mathrm{~km} / \mathrm{h})$. Standard deviation for the results in this group was 2.07.

The midfielders of the four top teams of the tournament had the mean speed of $8.16 \mathrm{~m} / \mathrm{s}(29.37 \mathrm{~km} / \mathrm{h})$. Standard deviation for the presented results in the group of midfielders was 2.09 . The analysis of the results of midfielders from the best teams competing during the World Cup showed that the midfielders of the Brazilian team had the speed of $8.33 \mathrm{~m} / \mathrm{s}(30 \mathrm{~km} / \mathrm{h})$, the midfielders from Germany had the mean speed of $8.30 \mathrm{~m} / \mathrm{s}(29.88 \mathrm{~km} / \mathrm{h})$, the midfielders from Argentina $-8.18 \mathrm{~m} / \mathrm{s}(29.43 \mathrm{~km} / \mathrm{h})$ and the Dutch midfielders $-7.78 \mathrm{~m} / \mathrm{s}(28.01 \mathrm{~km} / \mathrm{h})$. 
Table 1. Mean maximum speeds of the four best teams of the tournament during the matches of the 2014 World Cup

\begin{tabular}{|c|c|c|c|c|c|c|c|c|}
\hline \multirow[t]{2}{*}{ Team } & \multicolumn{2}{|c|}{ 1. Argentina } & \multicolumn{2}{|c|}{ 2. Brazil } & \multicolumn{2}{|c|}{ 3. Germany } & \multicolumn{2}{|c|}{ 4. Netherlands } \\
\hline & player & speed $(\mathrm{m} / \mathrm{s})$ & player & speed $(\mathrm{m} / \mathrm{s})$ & player & speed $(\mathrm{m} / \mathrm{s})$ & player & speed $(\mathrm{m} / \mathrm{s})$ \\
\hline & Di Maria* & 9.17 & Neymar & 8.83 & Hummels & 8.97 & Vlaar* & 9.16 \\
\hline & Basanta* & 9.09 & Bernard & 8.83 & Öezil & 8.88 & Robben & 8.93 \\
\hline & Rojo & 8.83 & Silva & 8.78 & Boateng & 8.63 & Depay & 8.53 \\
\hline & Lavezzi & 8.78 & Gustavo & 8.73 & Müller & 8.47 & Lens & 8.48 \\
\hline & Garay & 8.72 & Ramires & 8.63 & Hoewedes & 8.47 & Indi & 8.48 \\
\hline & Palacio & 8.72 & Willan & 8.63 & Schurrle & 8.38 & Van Persie & 8.38 \\
\hline & Perez & 8.68 & Jô & 8.57 & Khedira & 8.27 & Sneijder & 8.38 \\
\hline & Agüero & 8.63 & Maicon & 8.48 & Kross & 8.27 & Kuyt & 8,32 \\
\hline \multirow[t]{10}{*}{ Results } & Higuain & 8.53 & Marcelo & 8.47 & Götze & 8.12 & Janmaat & 8,32 \\
\hline & Gago & 8.43 & Fernandinho & 8.47 & Schweinsteinger & 8.11 & Wijnaldum & 7,97 \\
\hline & Mascherano & 8.43 & Hulk & 8.43 & Klose & 8.06 & De Guzman & 7,96 \\
\hline & Messi & 8.43 & Maxwell & 8.32 & Lahm & 7.97 & De Vrij & 7,92 \\
\hline & Zabaleta & 8.22 & Luiz & 8.07 & Mertesacker & 7.82 & De Jong & 7,91 \\
\hline & Demichelis & 8.02 & Alves & 8.02 & Mustafi & 7.09 & Blind & 7,63 \\
\hline & Fernandez & 7.97 & Paulinho & 7.82 & & & Clasie & 6,68 \\
\hline & Biglia & 7.60 & Oscar & 7.72 & & & & \\
\hline & Rodriguez & 6.94 & Fred & 7.72 & & & & \\
\hline & & & Dante & 6.99 & & & & \\
\hline$M(\mathrm{~m} / \mathrm{s})$ & \multicolumn{2}{|c|}{8,42} & \multicolumn{2}{|c|}{8.31} & \multicolumn{2}{|c|}{8.25} & \multicolumn{2}{|c|}{8.20} \\
\hline $\mathrm{M}(\mathrm{m} / \mathrm{s})$ for teams & \multicolumn{2}{|c|}{$(S D=1.61)$} & & & & & & \\
\hline
\end{tabular}

Table 2. Mean maximum speeds of the defenders of the four best teams of the tournament during the matches of the 2014 World Cup

\begin{tabular}{|c|c|c|c|c|c|c|c|c|}
\hline \multirow[t]{2}{*}{ Team } & \multicolumn{2}{|c|}{ 1. Argentina } & \multicolumn{2}{|c|}{ 2. Netherlands } & \multicolumn{2}{|c|}{ 3. Germany } & \multicolumn{2}{|c|}{ 4. Brazil } \\
\hline & player & speed $(\mathrm{m} / \mathrm{s})$ & player & speed $(\mathrm{m} / \mathrm{s})$ & player & speed $(\mathrm{m} / \mathrm{s})$ & player & speed $(\mathrm{m} / \mathrm{s})$ \\
\hline \multirow{7}{*}{ Results } & Basanta* & 9.09 & Vlaar* & 9.16 & Hummels & 8.97 & Silva & 8.78 \\
\hline & Rojo & 8.83 & Indi & 8.48 & Boateng & 8.63 & Maicon & 8.48 \\
\hline & Garay & 8.72 & Janmaat & 8.32 & Hoewedes & 8.47 & Marcelo & 8.47 \\
\hline & Zabaleta & 8.22 & De Vrij & 7.92 & Mertesacker & 7.82 & Maxwell & 8.32 \\
\hline & Demichelis & 8.02 & Blind & 7.63 & Mustafi & 7.09 & Luiz & 8.07 \\
\hline & & & & & & & Alves & 8.02 \\
\hline & & & & & & & Dante & 6.99 \\
\hline$M(\mathrm{~m} / \mathrm{s})$ & \multicolumn{2}{|c|}{8.58} & \multicolumn{2}{|c|}{8.29} & \multicolumn{2}{|c|}{8.19} & \multicolumn{2}{|c|}{8.16} \\
\hline \multirow{2}{*}{$M(\mathrm{~m} / \mathrm{s})$ for teams } & \multicolumn{8}{|c|}{8.29} \\
\hline & \multicolumn{8}{|c|}{$(S D=2.07)$} \\
\hline
\end{tabular}

The mean result for the group of forwards was $8.48 \mathrm{~m} / \mathrm{s}(30.52 \mathrm{~km} / \mathrm{h})$ with standard deviation of 1.06 . Among the players in the most offensive playing positions the representatives of Argentina had the mean maximum speed of $8.62 \mathrm{~m} / \mathrm{s}(31.03 \mathrm{~km} / \mathrm{h})$. The Dutch forwards had the maximum speed of $8.52 \mathrm{~m} / \mathrm{s}(30.67 \mathrm{~km} / \mathrm{h})$, the Brazilian forwards $-8.48 \mathrm{~m} / \mathrm{s}(30.51 \mathrm{~km} / \mathrm{h})$, and the German forwards $8.26 \mathrm{~m} / \mathrm{s}(29.73 \mathrm{~km} / \mathrm{h})$. 
Tahle 3. Mean maximum speeds of the midfielders of the four best teams of the tournament during the games of the 2014 World Cup

\begin{tabular}{|c|c|c|c|c|c|c|c|c|}
\hline \multirow[t]{2}{*}{ Team } & \multicolumn{2}{|c|}{ 1. Brazil } & \multicolumn{2}{|c|}{ 2. Germany } & \multicolumn{2}{|c|}{ 3. Argentina } & \multicolumn{2}{|c|}{ 4. Netherlands } \\
\hline & player & speed $(\mathrm{m} / \mathrm{s})$ & player & speed $(\mathrm{m} / \mathrm{s})$ & player & speed $(\mathrm{m} / \mathrm{s})$ & player & speed $(\mathrm{m} / \mathrm{s})$ \\
\hline \multirow{7}{*}{ Results } & Gustavo & 8.73 & Öezil & 8.88 & Di Maria* & 9.17 & Sneijder & 8.38 \\
\hline & Ramires & 8.63 & Khedira & 8.27 & Perez & 8.68 & Wijnaldum & 7.97 \\
\hline & Willan & 8.63 & Kross & 8.27 & Gago & 8.43 & De Guzman & 7.96 \\
\hline & Fernandinho & 8.47 & Schweinsteinger & 8.11 & Mascherano & 8.43 & De Jong & 7.91 \\
\hline & Paulinho & 7.82 & Lahm & 7.97 & Fernandez & 7.97 & Clasie & 6.68 \\
\hline & Oscar & 7.72 & & & Biglia & 7.60 & & \\
\hline & & & & & Rodriguez & 6.94 & & \\
\hline $\mathrm{M}(\mathrm{m} / \mathrm{s})$ & \multicolumn{2}{|c|}{8.33} & \multicolumn{2}{|c|}{8.30} & \multicolumn{2}{|c|}{8.18} & \multicolumn{2}{|c|}{7.78} \\
\hline $\mathrm{M}(\mathrm{m} / \mathrm{s})$ for teams & & & & $\begin{array}{r}8 . \\
\text { (SD }\end{array}$ & $\begin{array}{l}16 \\
2.09)\end{array}$ & & & \\
\hline
\end{tabular}

$\mathrm{M}$ - mean, SD - standard deviation, ${ }^{*}$ - players who had the speed of $9 \mathrm{~m} / \mathrm{s}$ or more.

Table 4. Mean maximum speeds of forwards of the four best teams during the games of the 2014 World Cup

\begin{tabular}{|c|c|c|c|c|c|c|c|c|}
\hline \multirow[t]{2}{*}{ Team } & \multicolumn{2}{|c|}{ 1. Argentina } & \multicolumn{2}{|c|}{ 2. Netherlands } & \multicolumn{2}{|c|}{ 3. Brazil } & \multicolumn{2}{|c|}{ 4. Germany } \\
\hline & player & speed $(\mathrm{m} / \mathrm{s})$ & player & speed $(\mathrm{m} / \mathrm{s})$ & player & speed $(\mathrm{m} / \mathrm{s})$ & player & speed $(\mathrm{m} / \mathrm{s})$ \\
\hline \multirow{5}{*}{ Results } & Lavezzi & 8.78 & Robben & 8.93 & Neymar & 8.83 & Müller & 8.47 \\
\hline & Palacio & 8.72 & Depay & 8.53 & Bernard & 8.83 & Schurrle & 8.38 \\
\hline & Agüero & 8.63 & Lens & 8.48 & Jô & 8.57 & Götze & 8.12 \\
\hline & Higuain & 8.53 & Van Persie & 8.38 & Hulk & 8.43 & Klose & 8.06 \\
\hline & Messi & 8.43 & Kuyt & 8.32 & Fred & 7.72 & & \\
\hline$M(\mathrm{~m} / \mathrm{s})$ & \multicolumn{2}{|c|}{8.62} & \multicolumn{2}{|c|}{8.52} & \multicolumn{2}{|c|}{8.48} & \multicolumn{2}{|c|}{8.26} \\
\hline$M(\mathrm{~m} / \mathrm{s})$ for teams & \multicolumn{8}{|c|}{8.48} \\
\hline
\end{tabular}

$M$ - mean.

The mean maximum running speed of goalkeepers was $7.40 \mathrm{~m} / \mathrm{s}(26.65 \mathrm{~km} / \mathrm{h})$. Among them Manuel Neuer (Germany) had the maximum speed of $8.57 \mathrm{~m} / \mathrm{s}(30.85 \mathrm{~km} / \mathrm{h})$, followed by an Argentine Romero $-8.01 \mathrm{~m} / \mathrm{s}$ $(28.84 \mathrm{~km} / \mathrm{h})$, Cesar (Brazil) $-6.85 \mathrm{~m} / \mathrm{s}(24.66 \mathrm{~km} / \mathrm{h})$ and Cillassen (Netherlands) $-6.18 \mathrm{~m} / \mathrm{s}(22.25 \mathrm{~km} / \mathrm{h})$.

Tahle 5. Maximum running speeds of the goalkeepers of the four best teams of the 2014 World Cup during the games of the tournament

\begin{tabular}{lcccccccc}
\hline Team & \multicolumn{2}{c}{ 1. Germany } & \multicolumn{2}{c}{ 2. Argentina } & \multicolumn{2}{c}{ 3. Brazil } & \multicolumn{2}{c}{ 4. Netherlands } \\
\hline \multirow{2}{*}{ Results } & player & speed $(\mathrm{m} / \mathrm{s})$ & player & speed $(\mathrm{m} / \mathrm{s})$ & player & speed $(\mathrm{m} / \mathrm{s})$ & player & speed $(\mathrm{m} / \mathrm{s})$ \\
\cline { 2 - 11 } & Neuer & 8.57 & Romero & 8.01 & Cesar & 6.85 & Cillasen & 6.18 \\
\hline $\mathrm{M}(\mathrm{m} / \mathrm{s})$ for players & & & & & 7.40 & & & \\
\hline
\end{tabular}

One-way analysis of variance (ANOVA) did not show a statistically significant differences between the studied teams $(F=0.54 ; \mathrm{df}=3.60 ; p=0.654$ ) or between corresponding playing positions of various teams (defenders - 
$F=0.54 ; d f=3.18 ; p=0.664 ;$ midfielders $-F=0.99 ; d f=3.19 ; p=0.420 ;$ forwards $-F=1.19 ; d f=3.15 ; p=0.349$ ) in terms of mean maximum running speeds.

This means that the teams as well as groups of players in the corresponding playing positions of the best national teams competing during a world championship tournament do not differ significantly in terms of motor preparation including the level of speed abilities which determine, among other things, the dynamics of team's play.

\section{Discussion}

Motor preparation of football players to competition-related physical effort is one of the most important elements of long-term periodised training process. The above applies also to speed abilities including locomotor speed which according to the authors of this study may comprehensively predispose certain players to sport competition, and then differentiate their level of preparation. As a consequence it may affect the success of realisation of tactical activities of the whole team in a certain sport discipline and be an indicator of the team's dynamics of play (Chmura et al., 2010). Short, intensive runs, i.e. sprints, are performed in many sports, in particular in contact team sports such as football, basketball and hockey (Ferro et al., 2014).

The analysis of maximum locomotor speed of the four best teams of the 2014 World Cup showed that mean maximum running speed of the players from national teams of Germany, Argentina, Netherlands and Brazil was $8.34 \mathrm{~m} / \mathrm{s}$ (in these groups the results of goalkeepers were not included in the calculations). Among the analysed team the Argentines had the speed of $8.42 \mathrm{~m} / \mathrm{s}$, the Brazilians $-8.31 \mathrm{~m} / \mathrm{s}$, the Germans $-8.25 \mathrm{~m} / \mathrm{s}$ and the Dutch $-8.20 \mathrm{~m} / \mathrm{s}$.

The mean speed for the four best goalkeepers of the 2014 FIFA World Cup was $7.40 \mathrm{~m} / \mathrm{s}$, while it was $8.29 \mathrm{~m} / \mathrm{s}$ for the defenders. Among the defenders the mean values were $8.58 \mathrm{~m} / \mathrm{s}$ for the Argentines, $8.29 \mathrm{~m} / \mathrm{s}$ for the Dutch, $8.19 \mathrm{~m} / \mathrm{s}$ for the Germans. The speed of $8.16 \mathrm{~m} / \mathrm{s}$ indicates an average level of speed preparation of Brazilian defenders, who conceded most goals among the analysed teams - 14 (Germany, Argentina and Netherlands conceded 4 goals each). The midfielders from the four top teams of the tournament has a mean maximum speed of $8.16 \mathrm{~m} / \mathrm{s}$, while for the Brazilian team midfielders it was $8.33 \mathrm{~m} / \mathrm{s}$, for the German team midfielders $8.30 \mathrm{~m} / \mathrm{s}$, for the Argentine midfielders $8.18 \mathrm{~m} / \mathrm{s}$ and for the Dutch midfielders $7.78 \mathrm{~m} / \mathrm{s}$. On the other hand, the mean maximum speed in the group of forwards was $8.48 \mathrm{~m} / \mathrm{s}$ (Argentina $-8.62 \mathrm{~m} / \mathrm{s}$, Netherlands $-8.52 \mathrm{~m} / \mathrm{s}$, Brazil $-8.48 \mathrm{~m} / \mathrm{s}$, Germany $-8.26 \mathrm{~m} / \mathrm{s}$ ). It should be noted here that in the comparison of the four national teams the German team was characterised by the highest level of shooting effectiveness. In seven games the DFB players scored in total 18 goals (while the Argentine scored 8, the Dutch 15 and the Brazilians 11).

Out of all studied players only three had maximum running speed exceeding $9 \mathrm{~m} / \mathrm{s}$. They were José María Basanta (Argentina), Ron Vlaar (Netherlands) and Ángel Di Maria (Argentina). In reference to these data Chmura et al. $(2010$, p. 86$)$ commented the presented level of speed abilities of the best footballers of the World Cup falling below expectations by writing: "the reasons for this can be seen, among other things, in a long and exhausting season, a large numbers of played games, and too short a recovery time after the season".

As we demonstrated in our analysis, among seventeen defenders of the four top teams of the tournament who had speed of $8 \mathrm{~m} / \mathrm{s}$, as many as twelve were nominally classified by their managers as central midfielders (Vlaar, Basanta, Hummels, Rojo, Silva, Garay, Boateng, Maicon, Hoewedes, Indi, Luiz and Demichelis). This may indicate the significance of the motor ability of speed and dynamics of motion in the effective action of players in playing positions 4 and 5 . On the other hand, among thirteen fastest midfielders of the teams from Germany, Argentina, 
Netherlands and Brazil who had speeds of at least $8 \mathrm{~m} / \mathrm{s}$, there is a significant difference, if we analyse them in terms of their nominal playing positions in midfield. For example, Ángel Di Maria is a player who usually plays in the national team on right wing or as a central offensive midfielder (position 7 or 10), Öezil, Willan and Sneijder are nominally central offensive midfielders (position 10), Perez, Fernandinho, Kroos and Schweinsteinger are central midfielders (position 8), whereas Luis Gustavo, Ramirez, Gago, Mascherano and Khedira are defensive midfielders (usually playing in position 6). This may indicate the fact that in modern football competition the differences is the level of speed predipositions become blurred between individual playing positions in the midfield. On the other hand, in the group of forwards, eighteen out of nineteen players (all forwards except for Brazilian Fred) "exceeded" the limit of locomotor speed of minimum $8 \mathrm{~m} / \mathrm{s}$. They were (in a decreasing order of maximum speeds) Robben, Neymar, Bernard, Lavezzi, Palacio, Agüero, Jô, Higuain, Depay, Müller, Lens, Messi, Hulk, Van Persie, Schuerrle, Kuyt, Götze and Klose. Perhaps this variable was the one that made the Brazil World Cup one of the most attractive in terms of the number of scored goals.

\section{Conclusions}

On the basis of the presented analysis of the four best teams of the FIFA World Cup in Brazil, the following final conclusions can be made corresponding to the research questions:

1. The mean maximum running speed of the four teams of the Mundial in Brazil was $8.34 \mathrm{~m} / \mathrm{s}$.

2. The mean maximum speed of the goalkeepers of the best four of the tournament was $7.40 \mathrm{~m} / \mathrm{s}$, while for defenders it was $8.29 \mathrm{~m} / \mathrm{s}$, for midfielders $-8.16 \mathrm{~m} / \mathrm{s}$, for forwards $-8.48 \mathrm{~m} / \mathrm{s}$.

Only three players at the 2014 World Cup had speeds of $9 \mathrm{~m} / \mathrm{s}$ or more. They were defenders Ron Vlaar $(9.16 \mathrm{~m} / \mathrm{s})$ and José María Basanta $(9,09 \mathrm{~m} / \mathrm{s})$ and a midfielder Ángel Di Maria $(9,17 \mathrm{~m} / \mathrm{s})$.

There are no significant differences in the level of maximum running speeds determining the dynamics of the game between the world's best teams and between their corresponding playing positions.

\section{References}

Bangsbo, J., Lorregaard, L., Thorsoe, F. (1991). Activity profile of competition soccer. Can J Sports Sci., 16 (2), $110-116$.

Bangsbo, J. (1999). Sprawność fizyczna piłkarza: naukowe podstawy treningu. Warszawa: COS.

Bompa, T., Zając A., Waśkiewicz, Z., Chmura, J. (2013). Przygotowanie sprawnościowe w zespołowych grach sportowych. Katowice: AWF.

Bradley, P.S., Sheldon, W., Wooster, B. Olsen, P., Boanas, P., Krustrup, P. (2009). High-intensity running in English FA Premier League soccer matches. Journal of Sports Sciences, 27 (2), 159-168.

Chmura, J. (2001). Szybkość w piłce nożnej. Katowice: AWF.

Chmura, P., Chmura, J., Kawczyński, A., Mroczek, D. (2010). Szybkościowe formy aktywności ruchowej piłkarzy na Mistrzostwach Świata w Piłce Nożnej 2010. Sport Wyczynowy, 4 (536), 80-87.

Chmura, P., Goliński, D., Andrzejewski, M., Mroczek, D., Kawczyński, A., Rokita, A., Chmura, J. (2014). Endurance capacity and selected technical-tactical skills of soccer players participating in the group stage of the 2014 FIFA World Cup. Trends in Sport Sciences, 3 (21), 153-160.

Cometti, G., Maffiuletti, N.A., Pousson, M., Chatard, J.C., Maffulli, N. (2001). Isokinetic Strength and Anaerobic Power of Elite, Subelite and Amateur French Soccer Players. Int J Sports Med., 22, 45-51.

Dargiewicz, R., Jastrzębski, Z. (2012). Kinematyka lokomocji piłkarzy nożnych na różnych etapach przygotowań. Gdańsk: AWFiS.

Dellal, A., Chamari, K., Wong, D.P., Ahmaidi, S., Keller, D., Barros, R.M.L., Bisciotti, G.N., Carling, Ch. (2011). Comparison of physical and technical performance in European soccer match-play: FA Premier League and La Liga. European Journal of Sport Science, $11(1), 51-59$. 
Di Salvo, V., Baron, R., Tschan, H., Calderon Montero, F.J., Bachl, N., Pigozzi, F. (2007). Performance characteristic according to playing position in elite soccer. International Journal \& Sports Medicine, 3, 222-227.

Faude, O., Koch, T., Meyer, T. (2012). Straight sprinting is the most frequent action in goal situations in professional football. J Sport Sci., 30, 625-631.

Ferro, A., Villacieros, J., Floría, P., Graupera, J.L. (2014). Analysis of Speed Performance In Soccer by a Playing Position and a Sports Level Using a Laser System. Journal of Human Kinetics, 44, 143-153.

Lago, C., Casais, L., Dominguez, E., Sampaio, J. (2010). The effects of situational variables on distance covered at various speeds in elite soccer. European Journal of Sport Science March., 10 (2), 103-107.

Mohr, M., Krustrup, P., Bangsbo, J. (2003). Match performance of high-standard soccer players with special reference to development of fatigue. Journal of Sports Sciences, 21, 519-528.

Cite this article aS: Bojkowski, Ł., Śliwowski, R., Wieczorek, A. (2016). Maximum Locomotor Speed of the Best Football Players at the FIFA World Cup in Brazil. Central European Journal of Sport Sciences and Medicine, 16 (4), 103-110. DOI: 10.18276/cej.2016.4-11. 